\title{
PENGARUH PROFITABILITAS, UKURAN PERUSAHAAN DAN INFLASI \\ TERHADAP RISIKO KREDIT BANK PERSERO PERIODE 2014-2018
}

\author{
Novi Arina Nainggolan \\ noviarina18@gmail.com \\ Frianto Pandia \\ friantopandia@yahoo.com \\ Ansori \\ Ansori1302@yahoo.com \\ Program Studi Keuangan dan Perbankan Terapan Politeknik Negeri Jakarta
}

\begin{abstract}
This study examines the effect of profitability, bank size and inflation on credit risk Persero Bank period 2014-2018. Indicators used are Net Interest Margin (NIM), Bank Size, Inflation and Non Performing Loan (NPL). The analysis method used in multiple linear regression analysis processed by using SPSS 25. The result of this study partially indicate that the profitability has positive significant effect on credit risk and inflation has negative significant effect on credit risk, while bank size has positive effect but no significant on credit risk. Simultaneously profitability, bank size and inflation have significant effect on credit risk of 56,2\% and the remaining $43,8 \%$ is required by other variables not used in this study.
\end{abstract}

Keywords: Profitability, Bank Size, Inflation, Credit Risk

\begin{abstract}
ABSTRAK
Penelitian ini bertujuan untuk mengetahui pengaruh profitabilitas, ukuran perusahaan dan inflasi terhadap risiko kredit bank persero di Indonesia periode 2014-2018. Indikator yang digunakan adalah Net Interest Margin (NIM), Bank Size Inflasi dan Non Performing Loan (NPL). Metode analisis yang digunakan adalah analisis regresi linear berganda yang diolah dengan menggunakan program SPSS 25. Hasil penelitian ini secara parsial menunjukkan bahwa profitabilitas berpengaruh positif signifikan terhadap risiko kredit serta ukuran perusahaan tidak berpengaruh signifikan terhadap risiko kredit. Sedangkan inflasi berpengaruh negatif signifikan terhadap risiko kredit. Secara simultan profitabilitas, ukuran perusahaan dan inflasi berpengaruh signifikan terhadap risiko kredit sebesar $56,2 \%$ dan sisanya sebesar $43,8 \%$ dipengaruhi oleh variabel lain yang tidak digunakan dalam penelitian ini.
\end{abstract}

Kata kunci: profitabilitas, ukuran perusahaan, inflasi dan risiko kredit

\section{PENDAHULUAN \\ Latar Belakang}

Pesatnya pertumbuhan ekonomi di suatu negara tidak terlepas dari sektor dunia Perbankan. Dunia perbankan merupakan salah satu institusi yang sangat berperan dalam bidang perekonomian suatu negara, khususnya di bidang pembiayaan perekonomian. Hal itu di dukung dengan Undang-undang Nomor 10 Tahun 1998 Pasal (4) yang menjelaskan Perbankan Indonesia bertujuan menunjang pelaksanaan pembangunan nasional dalam rangka meningkatkan pemerataan, pertumbuhan ekonomi, dan stabilitas nasional ke arah peningkatan kesejahteraan rakyat banyak.
Pada tahun 1997-1998 Indonesia pernah mengalami krisis moneter yang diawali melemahnya nilai tukar rupiah dengan valuta asing. Hal itu juga berdampak dalam penyaluran kredit pada saat itu. Tingkat kredit macet meningkat disebabkan lemahnya pengawasan sehingga banyak penyaluran kredit yang dilakukan bank swasta terkonsentrasi kepada debitur dalam satu grup (insider lending). Pada saat itu dunia perbankan tidak menerapkan prinsip prudensial banking yang baik dan tidak memperhatikan sisi kesehatan bank.

Untuk mengukur Tingkat Kesehatan Bank, perbankan di Indonesia menggunakan pendekatan yang digunakan dan disesuaikan 
dengan tingkat kesehatan menurut OJK melalui POJK No.4/POJK.03/2016 tentang Penilaian Tingkat Kesehatan Bank Umum. Menurut OJK, cakupan penelaian terhadap faktor profil risiko (risk profile), Good Corporate Govermance (GCG), rentabilitas (earnings) dan permodalan (capital).

Dalam aktivitas operasional bank tidak dapat dipisahkan dari risiko perbankan. Salah satu aktivitas operasional perbankan adalah penyaluran kredit. Bagi bank kredit merupakan bagian yang sangat penting, sebab kredit merupakan sumber utama pendapatan bagi bank selain pendapatan dari jasa dalam bentuk (fee based income).

Risiko kredit biasanya berupa macetnya pembayaran suatu kredit atau sering disebut dengan Non Performing Loan (NPL) atau pembiayaan bermasalah, yang dalam hal ini banyak faktor yang menyebabkan terjadinya NPL itu sendiri (Dewi dan Ramantha, 2015). Maka tidak semua kredit yang disalurkan kepada masyarakat bebas dari risiko, bahkan beberapa risiko dapat mengancam kesehatan bank. Perbankan harus menetapkan peranan manajemen risiko dalam mengatasi kegagalan pengembalian kredit oleh debitur, maka bank wajib mengukur tingkat risiko kredit dengan menggunakan perhitungan Non Performing Loan (NPL) yaitu rasio perbandingan total kredit bermasalah (kurang lancar, diragukan, macet) terhadap total kredit yang disalurkan.

Kredit macet dapat ditimbulkan oleh dua kemungkinan yaitu disebabkan oleh faktor internal dan faktor eksternal. Pada penelitian ini faktor eksternal yang mempengaruhi risiko kredit adalah profitabilitas dan ukuran perusahaan, sedangkan faktor eksternal adalah inflasi.

Profitabilitas merupakan kemampuan perusahaan menghasilkan laba dari hasil operasional. Dalam penelitian ini, rasio profitabilitas diukur dengan Net Interest Margin (NIM). NIM merupakan pengukuran mengenai perbedaan antara pendapatan bunga yang dihasilkan oleh bank atau lembaga keuangan lain dan nilai bunga yang dibayarkan kepada pemberi pinjaman. Semakin tinggi rasio net interest margin (NIM) menunjukkan semakin efektif kegiatan bank dalam memperoleh laba (Haryanto \& Widyarti, 2017). Penelitian yang dilakukan oleh Barus \& Erick (2016) mengemukakan bahwa NIM berpengaruh signifikan terhadap terjadinya
NPL. Hal tersebut bertentangan dengan penelitian Wati, Susyanti \& Salim (2017) menyatakan bahwa NIM tidak berpengaruh terhadap NPL.

Ukuran perusahaan adalah suatu skala pengukuran besar atau kecil suatu perusahaan berdasarkan total aset yang dimiliki perusahaan. Ukuran perusahaan dalam penelitian ini diproksikan dengan Bank Size. Bank Size merupakan suatu pengukuran perusahaan pada dasarnya merupakan hal yang penting dalam suatu perusahaan. Semakin besar aktiva atau asset yang dimiliki suatu bank maka semakin besar pula volume kredit yang dapat disalurkan oleh bank tersebut (Astrini, Suwendra dan Suwarna 2014). Volume kredit yang disalurkan besar, maka hal ini kemungkinan akan menyebabkan terjadinya kredit bermasalah karena terlalu banyak kredit yang disalurkan. Besarnya total aset yang dimiliki suatu bank akan mempengaruhi peningkatan terjadinya kredit bermasalah. Penelitian yang dilakukan Wati, Susyanti \& Salim (2017) mengemukakan bahwa Bank Size berpengaruh positif terhadap NPL. Sedangkan penelitian yang dilakukan oleh Kumala dan Suryantini (2015) menyatakan bahwa terdapat pengaruh tidak signifikan antara Bank Size dengan NPL.

Menurut BI, pengertian inflasi adalah kecenderungan harga-harga untuk meningkat secara umum dan terus menerus. Inflasi menaikan harga barang-barang didalam negeri. Hal ini akan mempengaruhi tingkat pendapatan rill masyarakat menjadi menurun, sehingga membuat debitur juga kesulitan untuk membayar. Nilai pendapatan yang relatif tidak berubah mendorong debitur kesulitan untuk membayarkan kewajibannya kepada bank. Penelitian yang dilakukan Linda, Megawati dan Deflinawati (2015) dan Barus \& Erick (2016) mengemukakan bahwa Inflasi berpengaruh positif terhadap NPL. Sedangkan penelitian yang dilakukan Rosita dan Musdholifah (2016) menyatakan bahwa terdapat tidak pengaruh positif antara Inflasi dengan NPL.

Perkembangan NPL pada bank Persero 5 tahun penelitian ini mengalami perubahan yang fluktuatif, namun Bank Persero masih mampu menjaga stabilitas kesehatan bank dengan rasio NPL masih dibawah $5 \%$ yaitu yang tertinggi ditahun 2016 sebesar 2,86\%. Begitu juga dengan perkembangan NIM mengalami perubahan yang fluktuatif 
cenderung kearah peningkatan, namun pada tahun 2017 mengalami penurunan hingga 2018 kondisi masih dalam kondisi aman Bank Persero masih menjaga rasio NIM diatas $2 \%$. Perkembangan bank size pada Bank Persero sangat menunjukan perkembangan yang baik sebab setiap tahunnya bank Persero selalu mengalami peninggkatan total aset pada ditahun 2018 aset yang dimiliki Bank Persero sebesar $\quad \mathrm{Rp} \quad 3,3$ triliun. Sedangkan perkembangan inflasi di Indonesia cukup berfluktuatif. Pada tahun 2014 inflasi di Indonesia cukup tinggi di angka 8,36\% akibatnya terjadi kenaikan harga BBM.

\section{Permasalahan}

Berdasarkan permasalahan pada latar belakang, maka rumusan masalah yang akan diteliti pada penelitian ini adalah:

1. Bagaimana pengaruh Profitabilitas terhadap Risiko Kredit pada bank PERSERO periode 2014-2018?

2. Bagaimana pengaruh Ukuran Perusahaan terhadap Risiko Kredit pada Bank PERSERO periode 2014-2018?

3. Bagaimana pengaruh Inflasi terhadap Risiko Kredit pada Bank PERSERO periode 2014-2018?

4. Bagaimana pengaruh Profitabilitas, Ukuran Perusahaan, dan Inflasi terhadap Risiko Kredit pada Bank PERSERO periode 20142018 ?

\section{Tujuan}

Merujuk pada permasalahan dan pertanyaan penelitian, penelitian ini bertujuan untuk:

1. Untuk mengetahui pengaruh secara simultan Profitabilitas, Ukuran Perusahaan, dan Inflasi terhadap Risiko Kredit pada Bank PERSERO periode 2014-2018.

2. Untuk mengetahui pengaruh secara parsial Profitabilitas, Ukuran Perusahaan, dan Inflasi terhadap Risiko Kredit pada Bank PERSERO periode 2014-2018.

\section{TINJAUAN PUSTAKA Pengertian Kredit}

Kredit merupakan aktiva produktif bank sebagai penghasilan utama yang diperoleh bank hasil operasional. Pengertian kredit menurut UU No. 10 tahun 1998 menyebutkan bahwa, "kredit adalah penyediaan uang atau tagihan yang dapat dipersamakan dengan itu, berdasarkan persetujuan atau kesepakatan pinjam meminjam antara bank dengan pihak lain yang mewajibkan pihak peminjam untuk melunasi utangnya setelah jangka waktu tertentu dengan pemberian bunga."

\section{Risiko Kredit}

Risiko kredit atau sering disebut default risk merupakan risiko akibat kegagalan atau ketidakmampuan nasabah mengembalikan jumlah pinjaman yang diperoleh dari perusahaan beserta bunganya sesuai dengan jangka waktu yang telah ditentukan. Surat Edaran OJK Nomor 14/SEOJK.03/2017 tentang Penilaian Tingkat Kesehatan Bank Umum, mendefinisikan risiko kredit sebagai risiko akibat kegagalan pihak lain dalam memenuhi kewajiban kepada bank, termasuk risiko kredit akibat kegagalan debitur, risiko konsentrasi kredit, counterparty risk credit dan settlement risk.

\section{Non Performing Loan}

Menurut Peraturan Otoritas Jasa Keuangan Nomor 15 /POJK.03/2017 Tentang Penetapan Status Dan Tindak Lanjut Pengawasan Bank Umum menyatakan bahwa, "kredit atau pembiayaan yang memiliki kualitas kurang lancar, diragukan, atau macet sebagaimana dimaksud dalam ketentuan peraturan perundang-undangan mengenai penilaian kualitas aset bank umum dan ketentuan OJK mengenai penilaian kualitas aset bank umum syariah dan unit usaha syariah. rasio kredit bermasalah secara neto (Non Performing Loan/NPL net) atau rasio pembiayaan bermasalah secara neto (Non Performing Financing/NPF net) lebih dari 5\% (lima persen) dari total kredit atau total pembiayaan." Rasio NPL dapat dihitung dengan menggunakan rumus sebagai berikut:

$$
\text { NPL }=\frac{\text { Kredit Bermasalah }}{\text { Total Kredit Yang Diberikan }} \times 100 \%
$$

\section{Profitabilitas}

Profititabilitas dalam kegiatan operasional perusahaan merupakan elemen penting untuk menjamin kelangsungan hidup perusahaan pada masa yang akan datang. Rasio profitabilitas atau disebut dengan rentabilitas adalah kemampuan suatu perusahaan untuk menghasilkan laba selama periode tertentu (Angela, dkk, 2018). Besarnya tingkat profitabilitas dapat menggambarkan kinerja perusahaan yang baik, artinya perusahaan sudah berjalan secara efektif dan efisien, maka perusahaan dapat memperluas usahanya (Intan dan Dodik, 2018).

\section{Net Interest Margin}


Net Interest Margin (NIM) merupakan rasio keuangan yang mengukur kemampuan bank dalam menghasilkan atas pengelolaan besar aktiva produktif. Keuntungan menggunakan rasio ini adalah bank dapat melihat seberapa besar tingkat jumlah pendapatan bunga bersih dengan menggunakan aktiva produktif yang dimiliki bank. Semakin tinggi rasio Net Interest Margin (NIM) menunjukkan semakin efektif kegiatan bank dalam memperoleh laba. Net Interest Margin (NIM) merupakan perbandingan antara pendapatan bunga bersih terhadap rata-rata aktiva produktifnya. Dapat dirumuskan sebagai berikut :

$$
\boldsymbol{N I M}=\frac{\text { Pendapatan Bunga Bersih }}{\text { Rata }- \text { rata Aktiva Produktif }} \times \mathbf{1 0 0} \%
$$

\section{Ukuran Perusahaan}

Ukuran ini biasanya disajikan dalam kapitalisasi, total aktiva, dan penjualan.Ukuran perusahaan yang semakin besar diukur dilihat dari besar penjualan, aktiva, dan kapitalisasi pasar (Dahlia, Jeni dan Agus, 2017). Bank size atau ukuran perusahaan pada dasarnya merupakan hal yang penting dalam suatu perusahaan. Ukuran perusahaan merupakan nilai yang menunjukkan besar kecilnya perusahaan (Kurniasih, 2012:148). Rasio bank size diperoleh dari total assets yang dimiliki bank yang bersangkutan jika dibandingkan dengan total assets dari bank-bank lain atau dirumuskan sebagai berikut:

$$
\text { Bank Size = Ln(Total Assets })
$$

\section{Inflasi}

Inflasi adalah suatu keadaan yang menunjukkan besar kecilnya kenaikan harga barang pada suatu negara. Inflasi adalah sebuah nilai ketika tingkat dari harga yang berlaku di dalam suatu bidang ekonomi. Bank Indonesia (BI) mendefinisikan inflasi dalam Inflation Targeting Framework bahwa Inflasi adalah kecenderungan harga-harga untuk meningkat secara umum dan terus menerus. Inflasi dapat dihitung menurut rumus berikut:

$$
\text { Inflasi }=\frac{\text { Total Inflasi }}{12} \times 100 \%
$$

\section{Kerangka Pemikiran Penelitian}

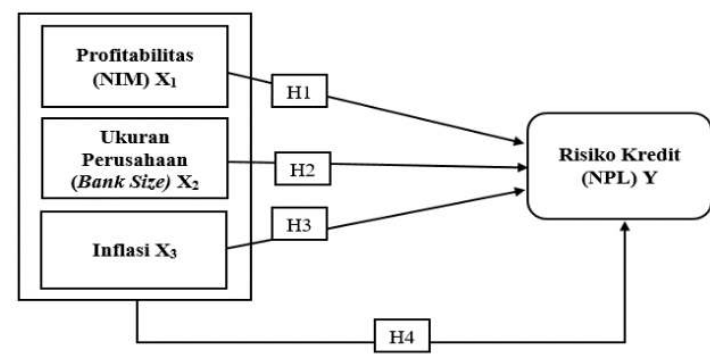

Gambar 1 Kerangka Pemikiran Penelitian

\section{Hipotesis Penelitian}

H1: Profitabilitas secara parsial memiliki pengaruh terhadap Risiko Kredit

H2: Ukuran Perusahaan secara parsial memiliki pengaruh terhadap Risiko Kredit

H3: Inflasi secara parsial memiliki pengaruh terhadap Risiko Kredit

H4: Profitabilitas, Ukuran Perusahaan dan Inflasi secara simultan memiliki pengaruh terhadap Risiko Kredit

\section{METODE PENELITIAN}

Jenis penelitian ini adalah penelitian asosiatif, yakni menganalisis pengaruh yang terjadi antara variabel yang satu dengan variabel yang lainnya. Selain itu, penelitian ini menggunakan metode pendekatan kuantitatif, yakni analisis data bersifat kuantitatif atau statistik tujuan untuk menguji hipotesis yang telah ditetapkan. Populasi dalam penelitian ini adalah laporan keuangan perbankan yang ada di Indonesia. Teknik sampling yang digunakan adalah purposive sampling yakni berdasarkan kriteria:

1. Bank persero yang telah terdaftar di Otoritas Jasa Keuangan, serta telah menerbitkan laporan keuangan bulanan selama 5 tahun berturut-turut periode 20142018.

2. Bank persero yang terdaftar di OJK ke dalam bank dengan total aset paling diatas Rp. 50.000.000.000.000,00.

Dari kriteria diatas sehingga sampel yang digunakan bank persero. Maka data yang didapat sebanyak 60 data. Teknik analisis yang digunakan ialah metode regresi linier berganda yang diolah menggunakan SPSS 25

\section{HASIL DAN PEMBAHASAN Statistik Deskriptif}


Statistik uji deskriptif penelitian ini dapat diketahui bahwa jumlah data (n) yang digunakan dalam penelitian ini adalah 60. Data rasio NPL pada Bank PERSERO minimum 1,94 dan nilai maksimum 3,12. Rata-rata NPL yakni 2,6265. Nilai standar deviasi sebesar 0,31698 lebih rendah dari nilai mean menunjukan bahwa tidak adanya kesimpangan data yang besar.Nilai minimum Inflasi adalah 2,79 dan nilai maksimum 8,36 . Nilai standar deviasi Inflasi yakni 1,69115 lebih rendah dari nilai mean yaitu sebesar 4,6678. Sedangkan variabel Net Interest Margin memiliki nilai minimum sebesar 4,84 dan nilai maksimum 6,40 . Nilai standar deviasi NIM yakni 0,44533 lebih rendah dari nilai mean yaitu sebesar 5,7893. Hasil ini menunjukan tidak adanya kesenjangan pada data. Berikut tabel hasil uji Deskriptif.

Tabel 1 Hasil Uji Deskriptif Descriptive Statistics

\begin{tabular}{|l|c|c|c|c|c|}
\hline & $\mathrm{N}$ & Min & Max & Mean & $\begin{array}{c}\text { Std. } \\
\text { Deviation }\end{array}$ \\
\hline NIM & 60 & 4,84 & 6,40 & 5,7893 &, 44533 \\
\hline $\begin{array}{l}\text { BANK } \\
\text { SIZE }\end{array}$ & 60 & 35,1 & 35,75 & 35,411 &, 18660 \\
\hline INFLASI & 60 & 2,79 & 8,36 & 4,6678 & 1,69115 \\
\hline NPL & 60 & 1,94 & 3,12 & 2,6265 &, 31698 \\
\hline $\begin{array}{l}\text { Valid N } \\
\text { (listwise) }\end{array}$ & 60 & & & & \\
\hline
\end{tabular}

Sumber : Hasil Output SPSS 25

\section{Uji Asumsi Klasik}

Uji Normalitas

Tabel 2 Hasil Uji Kolmogorov Smirnov

One-Sample Kolmogorov-Smirnov Test

\begin{tabular}{|l|l|r|}
\hline \multicolumn{2}{|c|}{} & \multicolumn{1}{|c|}{$\begin{array}{c}\text { Unstandardized } \\
\text { Residual }\end{array}$} \\
\hline $\mathrm{N}$ & 60 \\
\hline $\begin{array}{l}\text { Normal } \\
\text { Parameters }\end{array}$ & Mean &, 0000000 \\
\cline { 2 - 3 } $\begin{array}{l}\text { Most Extreme } \\
\text { Differences }\end{array}$ & Std. Deviation &, 20432552 \\
\cline { 2 - 3 } & Absolute &, 079 \\
\cline { 2 - 3 } & Positive &, 059 \\
\hline Test Statistic & Negative &,- 079 \\
\hline Asymp. Sig. (2-tailed) &, 079 \\
\hline \multicolumn{2}{|l|}{ a. Test distribution } &, $200^{\mathrm{c}, \mathrm{d}}$ \\
\hline
\end{tabular}

a. Test distribution is Normal.

b. Calculated from data.

c. Lilliefors Significance Correction.

$d$. This is a lower bound of the true significance.

Hasil Uji Kolmogorov Smirnov menggunakan program SPSS. Dari tabel diatas dapat dilihat bahwa signifikansi Uji Kolmogorov Smirnov sebesar 0,200. Nilai ini lebih besar dari ketentuan signifikansi yaitu 0,05 dan hal ini mengidentifikasi bahwa data telah terdistribusi normal dan model regresi dapat digunakan dalam penelitian ini.

\section{Uji Multikolinieritas}

Uji multikolineritas penelitian ini, di peroleh nilai VIF variabel NIM sebesar 1,239 yang artinya $1,239<10$, dan niai tolerance diperoleh sebesar 0,807 yang artinya $0,807>$ 0,10 . Untuk variabel Bank Size nilai VIF sebesar 2,645 yang artinya $2,645<10$, dan niai tolerance diperoleh sebesar 0,378 yang artinya $0,378>0,10$. Sedangkan untuk variabel Inflasi nilai VIF sebesar 2,667 yang artinya 2,667 <10, dan niai tolerance diperoleh sebesar 0,375 yang artinya $0,375>0,10$. Maka, dapat dinyatakan bahwa tidak terjadi gejala multikolinieritas karena dasar pengambilan keputusan dapat terpenuhi. Dengan dibuktikan tabel uji multikolineritas sebagi berikut :

\section{Tabel 3 Hasil Uji Multikolinieritas}

\section{Coefficients $^{\mathrm{a}}$}

\begin{tabular}{|l|l|r|r|}
\hline \multicolumn{2}{|c|}{ Model } & \multicolumn{2}{c|}{ Collinearity Statistics } \\
\cline { 3 - 4 } & Tolerance & \multicolumn{1}{c|}{ VIF } \\
\hline \multirow{3}{*}{} & (Constant) & & \\
\cline { 2 - 4 } & NIM &, 807 & 1,239 \\
\cline { 2 - 4 } & BANK SIZE &, 378 & 2,645 \\
\cline { 2 - 4 } & INFLASI &, 375 & 2,667 \\
\hline
\end{tabular}

a. Dependent Variable: NPL

Sumber : Hasil Output SPSS Versi 25

\section{Uji Heteroskedastisitas}

Tabel 4 Hasil Uji Heteroskedastisitas

\begin{tabular}{|c|c|c|c|}
\hline \multicolumn{4}{|c|}{ Coefficients $^{\mathrm{a}}$} \\
\hline & & $\mathrm{t}$ & Sig. \\
\hline \multirow[t]{4}{*}{1} & (Constant) & $-1,245$ & ,218 \\
\hline & NIM &,- 850 & ,399 \\
\hline & BANK SIZE & 1,330 & , 189 \\
\hline & INFLASI &,- 405 & 687 \\
\hline
\end{tabular}

a. Dependent Variable: RES2

Sumber : Hasil Output SPSS Versi 25

Berdasarkan tabel diatas hasil uji heteroskedastisitas, dapat dilihat bahwa nilai signifikansi untuk variabel independen yaitu berada diatas 0,05 yaitu masing-masing sebesar 0,399 untuk net interest margin, 0,189 untuk bank size dan 0,687 untuk inflasi.

\section{Uji Autokorelasi}

Tabel 5 Hasil Uji Autokorelasi

Model Summary ${ }^{b}$ 


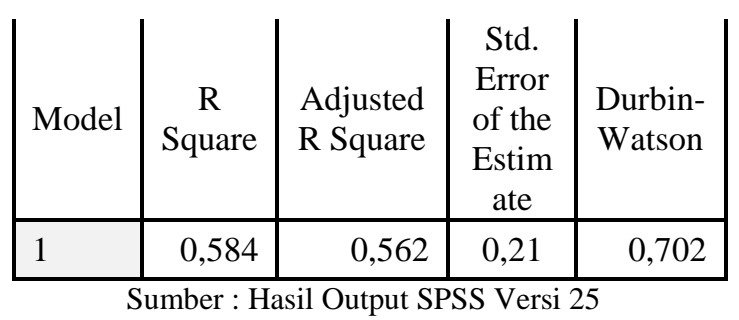

Uji autokorelasi dilihat berdasarkan hasil uji Durbin-Watson pada tabel dibawah menunjukan nilai Durbin-Watson sebesar 0,702. Berdasarkan kriteria yang telah disebutkan sebelumnya apabila angka DurbinWatson berada diantara -2 sampai +2 maka tidak terdapat autokorelasi. Tabel diatas menunjukan nilai Durbin-Watson sebessr 0,702 yang terletak diantara -2 sampai +2 . Maka dapat disimpukan bahwa model regresi pada penelitian ini tidak terdapat autokorelasi.

\section{Uji Regresi Linier Berganda}

Tabel 6 Hasil Uji Regresi Linier Berganda Coefficients $^{\mathrm{a}}$

\begin{tabular}{|c|c|c|}
\hline \multirow[b]{2}{*}{ Model } & \multicolumn{2}{|c|}{$\begin{array}{c}\text { Unstandardized } \\
\text { Coefficients }\end{array}$} \\
\hline & B & Std. Error \\
\hline $\begin{array}{ll}1 & \text { (Constant) }\end{array}$ & $-4,323$ & 8,471 \\
\hline NIM & ,340 & ,068 \\
\hline BANK SIZE & , 149 & 238 \\
\hline INFLASI &,- 066 & 026 \\
\hline
\end{tabular}

a. Dependent Variable: NPL

Sumber : Hasil Output Versi SPSS 25

Maka berdasarkan tabel diatas, dapat dirumuskan persamaan regresi linier berganda sebagai berikut :

$\begin{aligned} \text { NPL }= & -4,323+0,340 \text { NIM + LN 0,149 Bank } \\ & \text { Size }-0,066 \text { Inflasi + e } \\ & \text { Dari angka yang dihasilkan dari }\end{aligned}$ pengujian diatas, maka dapat dijelaskan sebagai berikut :

a. Pada persamaan terlihat bahwa nilai konstanta yang dihasilkan adalah sebesar (4,323), hasil yang diperoleh menunjukan bahwa ketika Net Interest Margin, Bank Size, dan Inflasi dianggap tetap atau konstan, sehingga dapat disimpulkan bahwa tingkat rasio non performing loan pada bank PERSERO akan menurun sebesar 4,323 satuan dengan asumsi jika nilai variabel lainnya bernilai nol.

b. Pada persamaan regresi terlihat variabel Net Interest Margin memiliki koefisien regresi bertanda positif sebesar 0,340 yang berarti ketika diasumsikan terjadi kenaikan rasio Net Interest Margin sebesar 1 satuan akan mendorong meningkatnya nilai rasio Non Performing Loan yang dimiliki bank sebesar 0,340 satuan dan sebaliknya. Dengan asumsi faktor lain selain $\mathrm{Net}$ Interest Margin dianggap tetap atau konstan.

c. Pada persamaan regresi terlihat variabel bank size memiliki koefisien regresi bertanda positif sebesar 0,149 yang berarti ketika diasumsikan terjadi kenaikan rasio bank size sebesar 1 satuan akan mendorong meningkatnya nilai rasio Non Performing Loan yang dimiliki bank sebesar 0,149 satuan dan sebaliknya. Dengan asumsi faktor lain selain bank size dianggap tetap atau konstan.

d. Untuk variabel tingkat Inflasi, koefisien regresi bertanda negatif sebesar $-0,066$. Nilai tersebut menunjukan bahwa jika diasumsikan terjadi peningkatan inflasi di Indonesia sebesar 1 satuan akan mendorong menurunnya nilai Non Performing Loan sebesar 0,066 satuan dan sebaliknya. Dengan asumsi faktor lain selain Inflasi dianggap tetap atau konstan.

\section{Uji Hipotesis}

Uji t (Parsial)

\begin{tabular}{|c|c|c|c|}
\hline \multicolumn{4}{|c|}{ Coefficients $^{\mathrm{a}}$} \\
\hline & Model & $\mathrm{t}$ & Sig. \\
\hline \multirow[t]{4}{*}{1} & (Constant) & $-0,51$ & 0,612 \\
\hline & NIM & 4,979 & 0 \\
\hline & BANK SIZE & 0,628 & 0,533 \\
\hline & INFLASI & $-2,509$ & 0,015 \\
\hline
\end{tabular}

a. Dependent Variable: NPL

Sumber : Hasil Output Versi SPSS 25

Berdasarkan tabel diatas maka uji $\mathrm{t}$ (parsial) dapat di analisis sebagai berikut :

a. Profitabilitas (NIM) terhadap Risiko Kredit (NPL)

Hasil uji t pada tabel diatas didapatkan hasil untuk variabel profitabilitas (NIM) diperoleh nilai signifikan sebesar 0,000 . Jadi 0,000 (nilai signifikansi) $<0,05$. Pengujian ini juga dilakukan dengan membandingkan nilai $t_{\text {hitung }}$ dengan $t_{\text {tabel }}$. Dengan nilai $t_{\text {tabel }}$ sebesar 2,00324. Nilai $\mathrm{t}_{\text {hitung }}$ untuk variabel profitabilitas (NIM) sebesar 4,979, sehingga nilai $t_{\text {hitung }}>t_{\text {tabel. }}$. Dengan demikian dapat diambil keputusan 
bahwa $\mathrm{H}_{1}$ diterima yang artinya bahwa secara parsial variabel profitabilitas (NIM) berpengaruh positif signifikan terhadap risiko kredit (NPL) Bank Persero periode 2014-2018. Jadi, dapat disimpulkan bahwa hipotesis pertama dalam penelitian ini diterima

b. Ukuran Perusahaan (Bank Size) terhadap Risiko Kredit (NPL)

Hasil uji t pada tabel diatas didapatkan hasil untuk variabel Ukuran Perusahaan (Bank Size) diperoleh nilai signifikan sebesar 0,533. Jadi 0,533 (nilai signifikansi) > 0,05 . Pengujian ini juga dilakukan dengan membandingkan nilai $t_{\text {hitung }}$ dengan $t_{\text {tabel }}$. Dengan nilai tabel sebesar 2,00324 dan nilai $\mathrm{t}_{\text {hitung }}$ untuk variabel Bank Size sebesar 0,628, sehingga nilai $t_{\text {hitung }}<t_{\text {tabel. }}$ Dengan demikian dapat diambil keputusan bahwa $\mathrm{H}_{2}$ ditolak yang artinya bahwa secara parsial variabel Ukuran Perusahaan (Bank Size) tidak berpengaruh signifikan terhadap Risiko Kredit (NPL) Bank Persero periode 2014-2018. Jadi, dapat disimpulkan bahwa hipotesis kedua dalam penelitian ini ditolak.

c. Inflasi terhadap Risiko Kredit (NPL)

Hasil uji t pada tabel diatas tabel diatas didapatkan hasil untuk variabel Inflasi diperoleh nilai signifikan sebesar 0,015. Jadi 0,015 (nilai signifikansi) $>0,05$. Pengujian ini juga dilakukan dengan membandingkan nilai $t_{\text {hitung }}$ dengan $t_{\text {tabel }}$. Dengan nilai $t_{\text {tabel }}$ sebesar 2,00324 dan nilai $t_{\text {hitung }}$ untuk variabel Inflasi sebesar $(-2,509)$, sehingga nilai $t_{\text {hitung }}>t_{\text {tabel }}$. Dengan demikian dapat diambil keputusan bahwa $\mathrm{H}_{0}$ diterima dan $\mathrm{H}_{\mathrm{I}}$ ditolak, yang artinya bahwa secara parsial variabel Inflasi berpengaruh negatif signifikan terhadap risiko kredit (NPL). Jadi, dapat disimpulkan bahwa hipotesis ketiga dalam penelitian ini diterima.

\section{Uji F (Simultan)}

Berdasarkan pada tabel hasil uji $\mathrm{F}$ diperoleh nilai signifikan sebesar 0,000 dapat dinyatakan bahwa secara simultan Profitabilitas (NIM),Ukuran Perusahaan (Bank Size), dan Inflasi berpengaruh signifikan terhadap Risiko Kredit (NPL), karena 0,000 $<0,05$ atau dapat dikatakan $\mathrm{H}_{4}$ diterima. Pengujian ini juga dilakukan dengan membandingkan nilai fhitung dengan ftabel. Dengan nilai ftabel sebesar 2,77 dan nilai fhitung sebesar 26,257, sehingga nilai $\mathrm{F}$ hitung $>\mathrm{F}$ tabel, dengan demikian dapat diambil kesimpulan bahwa Profitabilitas (NIM),Ukuran Perusahaan (Bank Size), dan Inflasi berpengaruh signifikan terhadap Risiko Kredit (NPL) pada Bank Persero. Jadi, dapat disimpulkan bahwa hipotesis keempat dalam penelitian ini diterima. Berikut tabel hasil uji F :

\begin{tabular}{|c|c|c|c|}
\hline \multicolumn{4}{|c|}{ Tabel 8 Hasil Uji F } \\
\hline \multicolumn{2}{|c|}{ Model } & $\mathrm{F}$ & Sig. \\
\hline \multirow[t]{3}{*}{1} & Regression & 26,257 &, $000^{\mathrm{b}}$ \\
\hline & Residual & & \\
\hline & Total & & \\
\hline
\end{tabular}

Sumber : Hasil Output Versi SPSS 25

\section{Uji Koefisien Determinasi $\left(R^{2}\right)$}

Tabel 9 Hasil Uji Koefisien Determinasi $\left(\mathrm{R}^{2}\right)$ Model Summary ${ }^{b}$

\begin{tabular}{|l|r|r|r|}
\hline Model & \multicolumn{1}{|c|}{$\mathrm{R}$} & R Square & $\begin{array}{r}\text { Adjusted } \\
\text { R Square }\end{array}$ \\
\hline 1 &, $765^{\mathrm{a}}$ & 0,584 & 0,562 \\
\hline \multicolumn{4}{|c}{ Sumber : Hasil Output Versi SPSS 25}
\end{tabular}

Berdasarkan tabel diatas hasil output SPSS dapat dilihat bahwa dari hasil perhitungan diperoleh nilai koefisien determinasi (Adjusted $R$ Square) adalah sebesar 0,562 . Hal ini menggambarkan bahwa Risiko Kredit (NPL) bank PERSERO di Indonesia dipengaruhi oleh variabel Profitabilitas (NIM), Ukuran Perusahaan (Bank Size), dan Inflasi sebesar 56,2\% dan 43,8\% lainnya dapat dijelaskan oleh variabel lain diluar penelitian.

\section{KESIMPULAN}

Berdasarkan hasil analisis data dan pembahasan pada penilitian ini yang berjudul Pengaruh Profitabilitas, Ukuran Perusahaan dan Inflasi Terhadap Risiko Kredit dengan studi kasus bank PERSERO periode 2014-2018 telah dilakukan dengan menggunakan regresi linier berganda, dapat diperoleh kesimpulan bahwa:

1. Hasil penelitian menunjukan profitabilitas yang diproksikan rasio Net Interest Margin (NIM) memiliki pengaruh positif signifikan secara parsial terhadap risiko kredit yang diproksikan rasio Non 
Performing Loan (NPL) pada Bank Persero periode 2014-2018. Hal ini menunjukan bahwa setiap kenaikan nilai Net Interest Margin pada Bank Persero akan menaikan Non Performing Loan. Hal ini karena bank mampu menempatkan aktiva sehingga bank memperoleh laba yang besar. Laba yang diperoleh bank tinggi akan menyebabkan bank banyak menyalurkan dana ke masyarakat, sehingga dana yang banyak disalurkan akan memicu peningkatan kredit bermasalah.

2. Hasil penelitian menunjukan ukuran perusahaan yang diproksikan rasio Bank Size tidak berpengaruh signifikan secara parsial terhadap risiko kredit yang diproksikan rasio Non Performing Loan (NPL) pada Bank Persero periode 20142018. Bank size suatu pengukuran yang digunakan ukur mengukur besar suatu bank. Ukuran yang digunakan dalam mengukur suatu bank adalah total aset. Besarnya total aset suatu perbankan tidak mempengaruhi besar atau kecilnya risiko bermasalah yang diproksikan dengan rasio NPL, dikarenakan total aset yang diperoleh suatu bank tidak semata-mata hasil dari penyaluran kredit sebagian hasil pendapatan operasional dari luar penyaluran kredit. Peningkatan risiko kredit juga muncul faktor lain yang lebih menpengaruhi dari ukuran perusahaan.

3. Hasil penelitian menunjukan Inflasi memiliki pengaruh negatif signifikan secara parsial terhadap risiko kredit yang diproksikan rasio Non Performing Loan (NPL) pada Bank Persero periode 20142018. Hal ini menunjukan bahwa setiap kenaikan nilai Inflasi pada Bank Persero akan mengalami penurunan non performing loan. Hal ini terjadi kerena inflasi yang tinggi membuat harga-harga barang pokok menjadi meningkat. Peningkatan harga barang pokok membuat masyarakat susah untuk menabung ke bank, maka berdampak pada penurunan DPK. Penurunan DPK membuat bank sulit menyalurkan dana kredit sehingga mebuat rasio non performing loan menurun.

4. Hasil penelitian menunujukan Profitabilitas, Ukuran Perusahaan dan Inflasi memiliki pengaruh signifikan secara simultan terhadap Risiko Kredit pada Bank Persero periode 2014-2018. Di antara variabel independen yang terdiri dari $\mathrm{Net}$ Interest Margin (NIM), Bank Size, dan Inflasi yang paling dominan mempengaruhi kemampuan bank dalam mengatasi kredit bermasalah adalah net interest margin. Dapat dilihat dari nilai tertinggi pada kolam koefisien. Koefisien dari variabel NIM mempunyai nilai sebesar 0.340. Hal ini menunjukkan bahwa pengelolan earning yang baik dimiliki bank memang berperan penting terhadap meminimalisir terjadinya kredit bermasalah.

\section{KETERBATASAN}

Penelitian ini telah diusahakan dan dilaksanakan sesuai dengan prosedur ilmiah, namun demikian masih memiliki keterbatasan. Penelitian ini bersifat retrospektif, yang menggunakan data sekunder. Dalam penelitian ini, data sekunder yang digunakan adalah data rekam medis. Keterbatasan menggunakan data sekunder adalah jumlah data yang ditemukan tidak menyeluruh. Ini disebabkan oleh kemungkinan terdapat data yang hilang saat penyimpanan.

\section{DAFTAR PUSTAKA}

Ananta, Y. (2019, January 11). About Us: Tahun 2019, OJK Targetkan Kredit Perbankan Tumbuh 12-14\%. Diambil kembali dari CNBC Indonesia Web site: https://www.cnbcindonesia.com

Astrini, K. S., Suwendra, I. W., \& Suwarna, I. K. (2014). Pengaruh CAR, LDR, Dan Bank Size Terhadap NPL Pada Lembaga Perbankan Yang Terdaftar Di Bursa Efek Indonesia. e-Journal Bisma Universitas Pendidikan Ganesha Jurusan Manajemen (Volume 2 Tahun 2014).

Barus, A. C., \& Erick. (2016). Analisis FaktorFaktor Yang Mempengaruhi Non Performing Loan Pada Bank Umum Di Indonesia. Jurnal Wira Ekonomi Mikroskil, Volume 6, Nomor 02, Oktober 2016.

Bank Indonesia. (2019, April 20). Diambil kembali dari Undang-undang Nomor 10 Tahun 1998 Pasal (4): https://www.bi.go.id

Dewi, K. P., \& Ramantha, I. W. (2015). Pengaruh Loan Deposit Ratio, Suku Bunga SBI, Dan Bank Size Terhadap Non Performing Loan. ISSN: 2302-8556 
E-Jurnal Akuntansi Universitas Udayana 11.3 (2015): 909-920.

Kumala, P. A., \& Suryantini, N. P. (2015). Pengaruh Capital Adequacy Ratio, Bank Size Dan BI Rate Terhadap Risiko Kredit (NPL) Pada Perusahaan Perbankan. EJurnal Manajemen Unud, Vol. 4, No. 8, 2015 : 2228-2242 ISSN: 2302-8912.

Linda, M. R., Megawati, \& Deflinawati. (2015). Pengaruh Inflasi, Kurs Dan Tingkat Suku Bunga Terhadap Non Performing Loan Pada PT. Bank Tabungan Negara (Persero) Tbk Cabang Padang. Journal of Economic and Economic Education Vol.3 No.2 (137 145).

Peraturan Otoritas Jasa Keuangan. (2019, April 20). Diambil kembali dari Nomor 4/POJK.03/2016 tentang Penilaian Tingkat Kesehatan Bank Umum: https://www.ojk.go.id

Wati, D., Susyanti, J., \& Salim, M. (2017). Pengaruh Rasio Camels Dan Bank Size Terhadap Non Performing Loan (NPL) (Pada Bank Bumn Di Indonesia). $e-$ Jurnal Riset Manajemen PRODI MANAJEMEN.

Rosita, M., \& Musdholifah. (2016). Pengaruh Makroekonomi, Capital Adequacy
Ratio, Loan To Deposit Ratio Dan Pertumbuhan Kredit Terhadap Non Performing Loan Pada Bank Asing Di Indonesia Periode 2013-2014. BISMA (Bisnis dan Manajemen) Volume 8 No. 2 Februari 2016.

Haryanto, S. B., \& Widyarti, E. T. (2017). Analisis Pengaruh NIM, NPL, BOPO, BI Rate Dan CAR Terhadap Penyaluran Kredit Bank Umum. Go Public Periode Tahun 2012-2016. Diponegoro Journal Of Management Volume 6, Nomor 4, Tahun 2017, Halaman 1-11 ISSN (Online): 2337-3792.

\section{UCAPAN TERIMA KASIH}

Pada kesempatan ini, penulis mengucapkan terima kasih kepada berbagai pihak yang telah memberikan bimbingan, masukan, kritik, dan motivasi selama penyusunan skripsi ini, baik secara langsung maupun tidak langsung. 